\title{
EQUATION DECOMPOSITION METHOD FOR SOLVING OF PROBLEMS OF STATICS, VIBRATIONS AND STABILITY OF THIN-WALLED CONSTRUCTIONS
}

\author{
Elena B. Koreneva ${ }^{1}$, Valery R. Grosman ${ }^{2}$ \\ ${ }^{1}$ Moscow Higher Combined-Arms Command Academy, Moscow, RUSSIA \\ ${ }^{2}$ Moscow State Academy for River Transport, Moscow, RUSSIA
}

\begin{abstract}
The work suggests the effective equation decomposition method (EDM) for solving of statics, vibrations and stability problems of thin-walled constructions. This method is based on the partition of the initial problem on the consideration of more simple auxiliary problems. The additional unknown functions are introduced for definition of the sought solutions. The paper shows the method's advantages on the examples of the boundary value problems for rectangular areas. The problem of anisotropic plate resting on an elastic subgrade and subjected to an action of expanding forces acting in the middle surface and to transverse loads is under study. The plate's edges are elastically supported. Also free vibrations of the rectangular plates of variable thickness with different boundary conditions were under consideration. The approximate analytical solutions with high exactness are obtained.
\end{abstract}

Key words: equation decomposition method, boundary value problems, approximate analytical solutions.

\section{МЕТОД ДЕКОМПОЗИЦИИ УРАВНЕНИЙ ДЛЯ РЕШЕНИЯ ЗАДАЧ СТАТИКИ, КОЛЕБАНИЙ И УСТОЙЧИВОСТИ ТОНКОСТЕННЫХ КОНСТРУКЦИЙ}

\author{
Е.Б. Коренева ${ }^{1}$, В.Р. Гросман ${ }^{2}$ \\ ${ }^{1}$ Московское высшее общевойсковое командное орденов Жукова, Ленина и Октябрьской Революции \\ Краснознаменное училище, г. Москва, РОССИЯ \\ ${ }^{2}$ Московская государственная академия водного транспорта, г. Москва, РОССИЯ
}

\begin{abstract}
Аннотация: Для решения задач статики, колебаний и устойчивости тонкостенных конструкций в работе предлагается эффективный приближенный аналитический метод декомпозиции уравнений (МДУ). Этот метод основан на расчленении исходной краевой задачи на ряд более простых вспомогательных задач. В этих задачах вводятся подлежащие определению дополнительные искомые функции, позволяющие определить решение. В работе достоинства метода показаны на примерах рассмотрения следующих краевых задач для прямоугольных областей. Решается задача о пластине, сделанной из анизотропного материала, лежащей на упругом основании и находящейся под действием растягивающих сил, действующих в срединной плоскости, и поперечной нагрузки. Контур пластины упруго оперт. Изучаются также свободные колебания прямоугольной пластины переменной толщины с различными условиями закрепления. Получены приближенные аналитические решения, обладающие высокой точностью.
\end{abstract}

Ключевые слова: метод декомпозиции уравнений, краевая задача, приближенные аналитические решения.

\section{INTRODUCTION}

The equation decomposition method (EDM) was for the first time suggested and justified in the works [1], [2]. Linear and nonlinear statics, vibrations and stability problems of thin-walled constructions computation can be solved by means of EDM. At the first time this method was applied for solving of problems, containing variable parameters for rectangular areas in the works [3], [4]. This method is based on the fact that the stated problem is replaced by the con- 
sideration of more simple auxiliary problems containing additional unknown functions. The EDM has considerably high exactness. The present work suggests the solutions of urgent problems of thin-walled constructions computation, obtained by means of EDM.

\section{SOLVING OF BENDING PROBLEM OF THE RECTANGULAR ORTHOTROPIC PLATE, RESTING ON AN ELASTIC SUBGRADE AND SUBJECTED TO AN ACTION OF EXPANDING FORCES}

Let us consider the bending problem of the rectangular orthotropic plate, resting on an elastic subgrade, which properties are described by Winkler's model. The plate is subjected to an action of expanding forces effective in its middle surface and by transverse loads. The plate's boundary is elastically supported (Fig.1). The relevant resolving equation is:

$$
\begin{gathered}
D_{1} \frac{\partial^{4} w}{\partial x^{4}}+2 D_{3} \frac{\partial^{4} w}{\partial x^{2} \partial y^{2}}+D_{2} \frac{\partial^{4} w}{\partial x^{2} \partial y^{2}}+c w- \\
-p\left(\frac{\partial^{2} w}{\partial x^{2}}+\frac{\partial^{2} w}{\partial y^{2}}\right)=q
\end{gathered}
$$

where $c$ is the modulus of subgrade.

We have in the generally accepted notations [4]:

$$
D_{1}=\frac{E_{x}^{\prime} h^{3}}{12}, D_{2}=\frac{E_{y}{ }^{\prime} h^{3}}{12}, D_{3}=\left(E^{\prime \prime}+2 G\right) \frac{h^{3}}{12} \text {. }
$$

For isotropic plate we have:

$$
E_{x}{ }^{\prime}=E_{y}{ }^{\prime}=\frac{E}{1-\sigma^{2}}, \quad E^{\prime \prime}=\frac{\sigma E}{1-\sigma^{2}}, \quad G=\frac{E}{2(1+\sigma)} .
$$

The boundary conditions for the problem under examination have the following form:

$$
x= \pm a, w=0, M_{x}= \pm r_{1} \frac{\partial w}{\partial x}
$$

$$
x= \pm b, w=0, M_{y}= \pm r_{2} \frac{\partial w}{\partial y},
$$

where $r_{1}, r_{2}$ are the coefficients of the contour's elasticity.

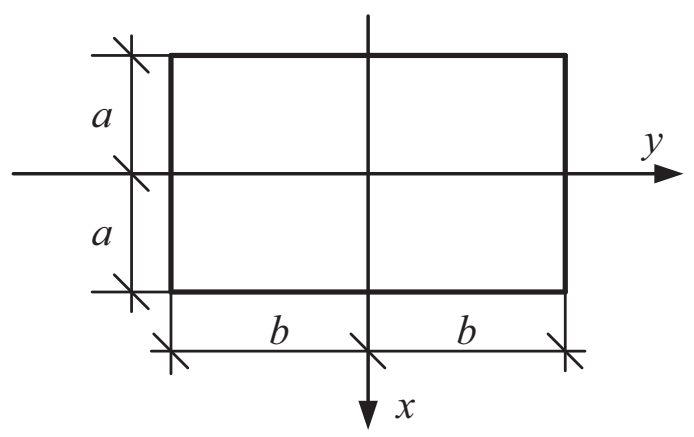

Fig.1. Rectangular plate with elastic contour

Taking into account the dimensionless elasticity coefficients:

$$
k_{1}=\frac{D}{D+r_{1} a}, k_{2}=\frac{D}{D+r_{2} b} \text {. }
$$

The conditions (2) can be represented in the following form:

when $x= \pm a$

$$
w=k_{1} a \frac{\partial^{2} w}{\partial x^{2}} \pm\left(1-k_{1}\right) \frac{\partial w}{\partial x}=0
$$

when $x= \pm b$

$$
w=k_{2} b \frac{\partial^{2} w}{\partial y^{2}} \pm\left(1-k_{2}\right) \frac{\partial w}{\partial y}=0 .
$$

It was taken into account that in the formulae (4), (5) the second terms in the expressions for $M_{x}$ and $M_{y}$ [4] on the contour, where $w=0$, are equal to zero. The values of $r_{1}$ and $r_{2}$ are positive or equal to zero. Therefore, according to the expressions (3), the coefficients $k_{1}$ and $k_{2}$ can change in the following way: $0 \leq k_{1} \leq 1$, $0 \leq k_{2} \leq 1$. The limiting values 0 and 1 corre- 
Equation Decomposition Method for Solving of Problems of Statics, Vibrations and Stability of Thin-Walled Construction

spond to the cases of rigid and simply supporting of the plate's boundary.

We will solve the boundary value problem (1), (4), (5) by means of the equation decomposition method (EDM). For this aim three auxiliary problems are introduced.

The first auxiliary problem (boundary) is to solve the differential equation

$$
D_{1} \frac{\partial^{4} w_{1}}{\partial x^{4}}-p \frac{\partial^{2} w_{1}}{\partial x^{2}}=f_{1}(x, y)
$$

with the boundary conditions (4) when $w=w_{1}$. The second auxiliary problem (boundary) is to solve the differential equation

$$
D_{2} \frac{\partial^{4} w_{2}}{\partial y^{4}}-p \frac{\partial^{2} w_{2}}{\partial y^{2}}=f_{2}(x, y)
$$

with the boundary conditions (5) when $w=w_{2}$. The third auxiliary problem is to solve the following differential equation:

$$
\begin{aligned}
\Phi(x, y)= & 2 D_{3} \frac{\partial^{4} w_{3}}{\partial x^{2} \partial y^{2}}+c w_{3}+f^{(1)}(x, y)+ \\
& +f^{(2)}(x, y)-q=0 .
\end{aligned}
$$

The solution of the initial problem (3), (4), (5) will coincide with the solutions of the auxiliary problems when the following equality will fulfilled:

$$
w=w_{1}=w_{2}=w_{3} .
$$

The mentioned conditions allow to determine the functions $f^{(1)}(x, y)$ and $f^{(2)}(x, y)$. We solve the posed task approximately. Let us present the sought functions $f^{(1)}(x, y)$ and $f^{(2)}(x, y)$ in the form of power series. The calculations and comparision of the received results for the deflections and the bending moments with the existing for certain boundary conditions exact solution show that we can retain two terms in these expansions:

$$
\begin{aligned}
& f^{(1)}(x, y)=f_{0}^{(1)}(y)+x^{2} f_{2}^{(1)}(y) ; \\
& f^{(2)}(x, y)=f_{0}^{(2)}(x)+y^{2} f_{2}^{(2)}(x) .
\end{aligned}
$$

Let us receive the solutions of the first and the second boundary value problems using the conditions (10). We obtain the following:

$$
\begin{gathered}
w^{(1)}=w^{(2)}=C_{1} \psi_{1}(x) \psi_{2}(y)+ \\
+C_{2} \psi_{1}(x) \psi_{4}(y)+C_{3} \psi_{3}(x) \psi_{2}(y)+ \\
+C_{4} \psi_{3}(x) \psi_{4}(y)
\end{gathered}
$$

where $\psi_{1}(x)=\varphi_{1}\left(x, a, \lambda_{1}, k_{1}\right)$,

$\psi_{2}(y)=\varphi_{1}\left(y, b, \lambda_{2}, k_{2}\right)$,

$\psi_{3}(x)=\varphi_{2}\left(x, a, \lambda_{1}, k_{1}, D_{1}\right)$,

$\psi_{4}(y)=\varphi_{2}\left(y, b, \lambda_{2}, k_{2}, D_{2}\right)$,

$$
\begin{gathered}
\varphi_{1}(z, d, \lambda, k)=\frac{1}{p}\left\{\frac{d(\operatorname{sh} \sqrt{\lambda} z-s h \sqrt{\lambda} d)}{\lambda\left[k d s h \sqrt{\lambda} d+(1-k) \frac{c h \sqrt{\lambda} d}{\sqrt{\lambda}}\right]}+\frac{d^{2}}{2}-\frac{z^{2}}{2}\right\}, \\
\times\left\{\frac{1}{\lambda} \frac{\varphi_{2}(z, d, \lambda, k, D)=\frac{1}{D \lambda^{2}} \times}{\left.k d\left(d^{2} \lambda+2\right)+(1-k)\left[\frac{d^{3}}{3} \lambda+2 d\right]\right]}(\operatorname{sh} \sqrt{\lambda} z-\operatorname{sh} \sqrt{\lambda} d)+\left[\frac{d^{4}}{12} \lambda+d^{2}\right]-\left[\frac{z^{4}}{12} \lambda+z^{2}\right]\right\}
\end{gathered}
$$


here $\lambda_{1}=\frac{p}{D_{1}}, \lambda_{2}=\frac{p}{D_{2}}, C_{1}, C_{2}, C_{3}, C_{4}$ - are the arbitrary constants.

The expression (11) is the approximate solution of the initial problem with the exactness up to four constants. Taking into account (11) and (9) we can determine these constants from the condition of the approximate solution of the differential equation (8) which takes the following form:

$$
\begin{gathered}
\Phi(x, y)=C_{1}\left[\psi_{1}(x)+\psi_{2}(y)+\right. \\
\left.+c \psi_{1}(x) \psi_{2}(y)+2 D_{3} \psi_{1}^{\prime \prime}(x) \psi_{2}^{\prime \prime}(y)\right]+ \\
+C_{2}\left[y^{2} \psi_{1}(x)+\psi_{4}(y)+c \psi_{1}(x) \psi_{4}(y)+\right. \\
\left.+2 D_{3} \psi_{1}^{\prime \prime}(x) \psi_{4}^{\prime \prime}(y)\right]+C_{3}\left[\psi_{3}(x)+\right. \\
+x^{2} \psi_{2}(y)+c \psi_{3}(x) \psi_{2}(y)+ \\
\left.+2 D_{3} \psi_{3}^{\prime \prime}(x) \psi_{2}^{\prime \prime}(y)\right]+C_{4}\left[y^{2} \psi_{3}(x)+\right. \\
+x^{2} \psi_{4}(y)+c \psi_{3}(x) \psi_{4}(y)+ \\
\left.+2 D_{3} \psi_{3}^{\prime \prime}(x) \psi_{4}^{\prime \prime}(y)\right]-q=0 .
\end{gathered}
$$

For receiving of the (12) approximate solution the following conditions are used when $x=y=0$ :

$$
\Phi=\frac{\partial^{2} \Phi}{\partial x^{2}}=\frac{\partial^{2} \Phi}{\partial y^{2}}=\frac{\partial^{4} \Phi}{\partial x^{2} \partial y^{2}}=0
$$

Thus the constants $C_{i}(i=1,2,3,4)$ are determined from the solution of the system of four equations in four unknowns. Then we can write the solution of the formulated problem by use (11).

The example for the square plate when $a=b$ was fulfilled. It was assumed that $k_{1}=k_{2}=1$ that is the all the edges are simply supported and $c=0$. The solution received by the help of EDM was compared with the existing for this case exact solution. It was shown that the values of the maximum deflection and bending moment in the plate's center which were received by the help of EDM differ from the exact solution respectively with $1,33 \%$ and $1,09 \%$.

\section{VIBRATIONS OF RECTANGULAR PLATES OF VARIABLE THICKNESS}

Natural vibrations of the rectangular plate (Fig.2) with the rigidity varying along one direction according to the exponential law

$$
D=D_{0} e^{b y}
$$

where $D_{0}, b$ are the constants, are under consideration.

The resolving differential equation has the form:

$$
\begin{gathered}
D\left\{\nabla^{2} \nabla^{2} W+2 b_{1} \frac{\partial}{\partial y} \nabla^{2} W+b_{1}^{2} \nabla^{2} W-\right. \\
\left.-b_{1}^{2}(1-\sigma) \frac{\partial^{2} W}{\partial x^{2}}\right\}+\frac{\gamma h}{g D} \frac{\partial^{2} W}{\partial t^{2}}=q,
\end{gathered}
$$

where $\frac{\gamma}{g}$ is the mass of the unit volume, $h$ is the plate's thickness.

After the separation of variables first we shall examine the case of the simply supporting of all the plate's edges (Fig.2).

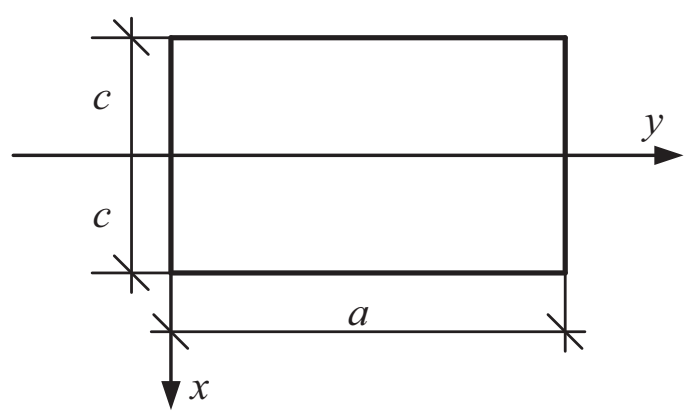

Fig.2. Rectangular plate of variable thickness

$$
\begin{aligned}
& x= \pm c, w=\frac{\partial^{2} w}{\partial x^{2}}=0 \\
& y=0, a, w=\frac{\partial^{2} w}{\partial y^{2}}=0
\end{aligned}
$$

Using the substitution (14) we obtain the equation: 
Equation Decomposition Method for Solving of Problems of Statics, Vibrations and Stability of Thin-Walled Construction

$$
\begin{gathered}
D_{0} e^{b_{1} y}\left(\nabla^{2} \nabla^{2} w+2 b_{1} \frac{\partial}{\partial y} \nabla^{2} w+b_{1}^{2} \nabla^{2} w-\right. \\
\left.-b_{1}^{2}(1-\sigma) \frac{\partial^{2} w}{\partial x^{2} \partial y^{2}}\right)-\lambda_{s} w=q,
\end{gathered}
$$

where $\lambda_{s}=\frac{\gamma h w^{2}}{g D}$.

Boundary value problem (16)-(18) will be solved by use of the EDM. For this aim the three auxiliary problems are introduced.

The first auxiliary problem (boundary): to receive the solution of the differential equation

$$
\frac{\partial^{4} w_{1}}{\partial x^{4}}+b^{2} \sigma \frac{\partial^{2} w_{1}}{\partial x^{2}}=f^{(1)}(x, y),
$$

satisfying the boundary conditions (16) when $w=w_{1}$.

The second auxiliary problem (boundary): to obtain the solution of the differential equation

$$
\begin{gathered}
D_{0} e^{b y}\left[\frac{\partial^{4} w_{2}}{\partial x^{4}}+2 b \frac{\partial^{3} w_{2}}{\partial y^{3}}+b^{2} \frac{\partial^{2} w_{2}}{\partial y^{2}}\right]= \\
=f^{(2)}(x, y),
\end{gathered}
$$

satisfying the boundary conditions (17) when $w=w_{2}$.

The third auxiliary problem: to receive the solution of the following differential equation:

$$
\begin{aligned}
& \Phi(x, y)=D_{0} e^{b_{1} y}\left[2\left(\frac{\partial^{4} w_{3}}{\partial x^{2} \partial y^{2}}+b \frac{\partial^{3} w_{3}}{\partial x^{2} \partial y}\right)+\right. \\
& \left.+f^{(1)}(x, y)\right]+f^{(2)}(x, y)-\lambda_{s} w_{3}-q=0 .
\end{aligned}
$$

The solution of the posed problem (16)-(18) will coincide with the solution of the auxiliary problems when the conditions of their equality (9) are fulfilled. These conditions allow to determine the auxiliary functions $f^{(1)}(x, y)$ and $f^{(2)}(x, y)$.

As well as in the previous example we solve the formulated problem approximately. We repre-

sent the functions $f^{(1)}(x, y)$ and $f^{(2)}(x, y)$ in the form of power series. The calculations showed that retaining of two members of power series is unsufficiently. For the mentioned case the comparision of the maximum values of the bending moments and the deflections received by the such way with the existing exact solution shows the deviations are respectively with $7,59 \%$ and $10,10 \%$. It was defined that for obtaining of the solution possessing high exactness we must accept the following expansions, taking into account the symmetry on the coordinate $x$ :

$$
\begin{aligned}
f^{(1)}(x, y) & =f_{0}^{(1)}(y)+x^{2} f_{2}^{(1)}(y) ; \\
f^{(2)}(x, y) & =f_{0}^{(2)}(x)+y f_{1}^{(2)}(x)+ \\
& +y^{2} f_{2}^{(2)}(x) .
\end{aligned}
$$

Solving the first boundary value problem (19) and (16) we receive:

$$
w_{1}=\psi_{1}(x) f_{0}^{(1)}(y)+\psi_{2}(x) f_{2}^{(1)}(y),
$$

where

$$
\begin{gathered}
\psi_{1}(x)=\frac{1}{\gamma_{1}^{2}}\left\{\frac{\cos \gamma_{1} x}{\gamma_{1}^{2} \cos \gamma_{1} c}-\left[\frac{1}{\gamma_{1}^{2}}+\frac{c^{2}}{2}\right]+\frac{x^{2}}{2}\right\}, \\
\psi_{2}(x)=\frac{1}{\gamma_{2}^{2}}\left\{\frac{\cos \gamma_{1} x}{\gamma_{1}^{2} \cos \gamma_{1} c}\left[c-\frac{2}{\gamma_{1}^{2}}\right]-\right. \\
\left.-\left[\frac{c^{4}}{12}-\frac{2}{\gamma_{1}^{4}}\right]+\left[\frac{x^{4}}{12}-\frac{x^{2}}{\gamma_{1}^{2}}\right]\right\}, \\
\gamma_{1}=b_{1} \sqrt{\sigma} .
\end{gathered}
$$

Solving the second boundary value problem (20) and (17) we obtain:

$$
\begin{gathered}
w_{2}=\psi_{3}(y) f_{0}^{(2)}(x)+\psi_{4}(y) f_{1}^{(2)}(x)+ \\
+\psi_{5}(y) f_{2}^{(2)}(x),
\end{gathered}
$$

where 


$$
\begin{aligned}
& \psi_{3}(y)=\frac{A}{b_{1}^{3}}\left\{-\frac{a}{2}\left(b_{1} e^{-b_{1} y}+2 e^{-b_{1} y}\right)-\left[e^{-a b_{1}}\left(1+\frac{3}{a b_{1}}\right)+\left(1-\frac{3}{a b_{1}}\right)\right] y+\left(a-\frac{3}{b_{1}}\right) y+\right. \\
& \left.+\frac{e^{-b_{1} y} b_{1}}{2}\left(y^{2}+\frac{4 y}{b_{1}}+\frac{6}{b_{1}^{2}}\right)\right\} \\
& \psi_{4}(y)=\frac{A}{6 b_{1}^{3}}\left\{-a^{2}\left(b_{1} e^{-b_{1} y} y+2 e^{-b_{1} y}\right)-y\left[2 e^{-a b_{1}}\left(2+\frac{9}{b_{1}}+\frac{12}{a b_{1}^{2}}\right)+\frac{2}{a}\left(a^{2}-\frac{12}{b_{1}^{2}}\right)\right]+\right. \\
& \left.+2\left(a^{2}-\frac{12}{b_{1}^{2}}\right)+e^{-b_{1} y} b_{1}\left(y^{3}+\frac{6 y^{2}}{b_{1}}+\frac{18 y}{b_{1}^{2}}+\frac{24}{b_{1}^{3}}\right)\right\} \\
& \psi_{5}(y)=\frac{A}{12 b_{1}^{3}}\left\{-a^{3}\left(b_{1} e^{-b_{1} y}+2 e^{-b_{1} y}\right)-\frac{12}{a}\left[\frac{e^{-b_{1} a}}{2}\left(a^{3}+\frac{6 a^{2}}{b_{1}}+\frac{16 a}{b_{1}^{2}}+\frac{20}{b_{1}^{3}}\right)+\left(\frac{a^{3}}{6}-\frac{10}{b_{1}^{3}}\right)\right] y+\right. \\
& \left.+2\left(a^{3}-\frac{60}{b_{1}^{3}}\right)+e^{-b_{1} y} b_{1}\left(y^{4}+\frac{8 y^{3}}{b_{1}}+\frac{36 y^{2}}{b_{1}^{2}}+\frac{96 y}{b_{1}^{3}}+\frac{120}{b_{1}^{4}}\right)\right\} \\
& A=\frac{1}{D_{0}} .
\end{aligned}
$$

Further using the equality (9) we receive:

$$
\begin{aligned}
w_{1}= & w_{2}=C_{1} \psi_{1}(x) \psi_{3}(y)+C_{2} \psi_{1}(x) \psi_{4}(y)+ \\
& +C_{3} \psi_{1}(x) \psi_{5}(y)+C_{4} \psi_{2}(x) \psi_{3}(y)+ \\
& +C_{5} \psi_{2}(x) \psi_{4}(y)+C_{6} \psi_{2}(x) \psi_{6}(y),
\end{aligned}
$$

where $C_{i}(i=1, \ldots, 6)$ are the arbitrary constants.

$$
\begin{aligned}
& \Phi(x, y)=C_{1}\left\{D_{0} e^{b_{1} y}\left\{2 \psi_{1}^{\prime \prime}(x)\left[\psi_{3}^{\prime \prime}(y)+b_{1} \psi_{3}^{\prime}(y)\right]+\psi_{3}(y)\right\}+\psi_{1}(x)\left[1-\lambda_{s} \psi_{3}(y)\right]\right\}+ \\
& +C_{2}\left\{D_{0} e^{b_{1} y}\left\{2 \psi_{1}^{\prime \prime}(x)\left[\psi_{4}^{\prime \prime}(y)+b_{1} \psi_{4}^{\prime}(y)\right]+\psi_{4}(y)\right\}+\psi_{1}(x)\left[y-\lambda_{s} \psi_{4}(y)\right]\right\}+ \\
& +C_{3}\left\{D_{0} e^{b_{1} y}\left\{2 \psi_{1}^{\prime \prime}(x)\left[\psi_{5}^{\prime \prime}(y)+b_{1} \psi_{5}^{\prime}(y)\right]+\psi_{5}(y)\right\}+\psi_{1}(x)\left[y^{2}-\lambda_{s} \psi_{5}(y)\right]\right\}+ \\
& +C_{4}\left\{D_{0} e^{b_{1} y}\left\{2 \psi_{2}^{\prime \prime}(x)\left[\psi_{3}^{\prime \prime}(y)+b_{1} \psi_{3}^{\prime}(y)\right]+x^{2} \psi_{3}(y)\right\}+\psi_{2}(x)\left[1-\lambda_{s} \psi_{3}(y)\right]\right\}+ \\
& +C_{5}\left\{D_{0} e^{b_{1} y}\left\{2 \psi_{2}^{\prime \prime}(x)\left[\psi_{4}^{\prime \prime}(y)+b_{1} \psi_{4}^{\prime}(y)\right]+x^{2} \psi_{4}(y)\right\}+\psi_{2}(x)\left[y-\lambda_{s} \psi_{4}(y)\right]\right\}+ \\
& +C_{6}\left\{D_{0} e^{b_{1} y}\left\{2 \psi_{2}^{\prime \prime}(x)\left[\psi_{5}^{\prime \prime}(y)+b_{1} \psi_{5}^{\prime}(y)\right]+x^{2} \psi_{5}(y)\right\}+\psi_{2}(x)\left[y^{2}-\lambda_{s} \psi_{5}(y)\right]\right\}-q=0 .
\end{aligned}
$$

For the estimation of the coefficients $C_{i}(i=1, \ldots, 6)$ the Bubnov-Galerkin's method may be used. Below the another effective method which was applied in the previous example will be used. Let us call $\Phi(x, y)$ as the residual function. This function is equal to zero in the exact solution. We minimize the residual function in the plate's midpoint when $x=0$, $y=a / 2$ for the determination of the constants $C_{i}(i=1, \ldots, 6)$. Evidently that the residual function in this section significantly affects on the approximate solution exactness. Therefore we will write the conditions of the equality to zero of the function $\Phi(x, y)$ and a few of its lower derivatives with respect to the arguments $x$ and $y$ when $x=0$ and $y=a / 2$ : 
Equation Decomposition Method for Solving of Problems of Statics, Vibrations and Stability of Thin-Walled Construction

$$
\Phi=\frac{\partial^{2} \Phi}{\partial x^{2}}=\frac{\partial \Phi}{\partial y}=\frac{\partial^{2} \Phi}{\partial y^{2}}=\frac{\partial^{4} \Phi}{\partial x^{4}}=\frac{\partial^{3} \Phi}{\partial x^{2} \partial y}=0
$$

It is taken into account that because of symmetry with respect to the argument $x$ the odd derivatives on $x$ are equal to zero. Further the system of the six equations with six unknown values is under consideration for the aim of the constants $C_{i}$ determination. Then the deflections and the stresses are defined.

Let us examine the bending of the rectangular plate with the rigidity (14) with another boundary conditions; the edges

$$
y=0, a
$$

are simply supported and the edges

$$
x= \pm a
$$

are clamped, that is we have:

$$
x= \pm c, w=\frac{\partial w}{\partial x}=0
$$

Then the solution of the first boundary value problem is to solve the differential equation (19) with the boundary conditions (31). As a result we obtain the following relations for the functions $\psi_{1}(x)$ and $\psi_{2}(x)$ :

$$
\begin{gathered}
\psi_{1}(x)=\frac{c}{\gamma_{1}^{2}}\left\{\frac{\cos \gamma_{1} x}{\gamma_{1} \sin \gamma_{1} c}-\left[\frac{\operatorname{ctg} \gamma_{1} c}{\gamma_{1}}+\frac{c}{2}\right]+\frac{x^{2}}{2 c}\right\}, \\
\psi_{2}(x)=\frac{c}{\gamma_{1}^{2}}\left\{\frac{\cos \gamma_{1} x}{\gamma_{1}^{2} \sin \gamma_{1} c}\left(\frac{c^{2}}{3}-\frac{2}{\gamma_{1}^{2}}\right)-\right. \\
-\left[\frac{1}{\gamma_{1}} \operatorname{ctg} \gamma_{1} c\left(\frac{c^{2}}{3}-\frac{2}{\gamma_{1}^{2}}\right)+c\left(\frac{c^{2}}{12}-\frac{1}{\gamma_{1}^{2}}\right)\right]+ \\
\left.+\frac{1}{c}\left(\frac{x^{4}}{12}-\frac{x^{2}}{\gamma_{1}^{2}}\right)\right\}, \\
\gamma_{1}=b_{1} \sqrt{\sigma} .
\end{gathered}
$$

The solution of the second boundary value problem remains unvariable and is represented by

the expression (24) where the functions $\psi_{3}(y)$, $\psi_{4}(y), \psi_{5}(y)$ are defined by the relations (25). Then the deflections and the stresses are determined in the same way as it was described above.

\section{CONCLUSION}

The work stated the equation decomposition method intended for solving of boundary value problems of thin-walled structures computation. This method is based on the fact that the consideration of the original problem is replaced by the examination of the auxiliary problems including boundary value ones. For the consideration of the mentioned problems the auxiliary functions are introduced. The approximate analytical solutions possessing high exactness are obtained.

\section{REFERENCES}

1. Pshenichnov G.I. Metod Dekompozitsii Uravnenij i Kraevyh Zadach. [Equation Decomposition Method for Solving of Equations and Boundary Value Problems] // Doklady AN SSSR. 1985, t.282, №4, pp. 792-794 (in Russian).

2. Pshenichnov G.I. A Theory of Latticed Plates and Shells. World Scientific. Singapore, New Jersey, London, Hong Kong, 1993, 309 pages.

3. Koreneva E.B., Pshenichnov G.I. Primenenie Metoda Dekompozitsii Uravnenij k Resheniju Zadach Teorii Izgiba Plastin Peremennoj Tolshiny [Equation Decomposition Method Application for Solving of Bending Problems of Plates of Variable Thickness] // Zhurnal Vychislitelnoj Matematiki i Matematicheskoj Phyziki. 1997. №3, pp. 553-558 (in Russian).

4. Koreneva E.B. Analiticheskie Metody Rascheta Plastin Peremennoj Tolschiny i ih Prakticheskije Prilozhenija [Analylical Methods for Calculation of Plates with Vary- 
ing Thickness and Their Practical Application]. Moscow, ASV, 2009, 238 p. (in Russian).

\section{СПИСОК ЛИТЕРАТУРЫ}

1. Пшеничнов Г.И. Метод декомпозиции решения уравнений и краевых задач. // Доклады А.Н. СССР, 1985, том 282, №4, c. 792-794.

2. Pshenichnov G.I. A Theory of Latticed Plates and Shells. World Scientific. Singapore, New Jersey, London, Hong Kong, 1993, 309 pages.

3. Коренева Е.Б., Пшеничнов Г.И. Применение метода декомпозиции уравнений к решению задач теории изгиба пластин переменной толщины. // Журнал вычислительной математики и математической физики, 1997, №3, с. 553-558.

4. Коренева Е.Б. Аналитические методы расчета пластин переменной толщины и их практические приложения. - М.: ACB, 2009. - $238 \mathrm{c}$.

Elena B. Koreneva, Dr.Sc., Professor, Dr.Sc., Moscow Higher Combined-Arms Command Academy; 2, ul. Golovacheva, Moscow, 109380, Russia,

tel.: +7(499)175-82-45;

E-mail: elena.koreneva2010@yandex.ru.

Valery R. Grosman, Associate Professor, Moscow State Academy for River Transport; 2, k. 1, Novodanilovskaya nab., Moscow, 117105, Russia; phone: +7(499)618-52-56; E-mail: elena.koreneva2010@yandex.ru.

Коренева Елена Борисовна, доктор технических наук, профессор, Московское высшее общевойсковое командное орденов Жукова, Ленина и Октябрьской Революции Краснознаменное училище; 109380, Россия, г. Москва, ул. Головачева, д. 2 ; тел.: +7(499)175-82-45;

E-mail: elena.koreneva2010@yandex.ru.

Гросман Валерий Романович, старший преподаватель, МГАВТ - филиал ФГБОУ ВО «ГУМРФ имени адмирала С.О. Макарова»; 117105, Россия, г. Москва, Новоданиловская наб., д. 2, корп. 1;

тел.: +7(499)618-52-56;
E-mail: elena.koreneva2010@yandex.ru. 